\title{
The Ivanaj Reform and Its Impact on the Italian-Albanian Relations
}

\section{Phd candidate Antoneta Hoxha}

\section{Doi:10.5901/ajis.2014.v3n3p301}

\author{
History and Geography \\ ani_hoxha87@hotmail.com
}

\begin{abstract}
In 1931-1935 there have been numerous events that played an important role in Albanian foreign political orientation, governed by AhmetZogu at that time. The King Zog, tried to make an independent foreign policy by approaching to its neighbour countries and by establishing new political relations as a result of an anti- italianism stream created in the country, as well as a result of the italian interventions and the fear from italian influence. The Government of Tirana undertook a series of measures that reconfirmed the independent line, which were against italian politics in Albania. One of these reforms was the educational reform of 1933 for the nationalization of the Albanian school and making it a national school, known in the history as "Ivanaj Reform". This reform, with a nationalist character, that intended the national school unification led to the closure of all the private and foreign schools in Albania. There were immediate reactions from the foreign and local press toward this event, but the toughest attitudes were from neighbor countries. As e response Italy decided to cut all financial aids. Whereas Greece accused for violations toward greek minority rights and brought the issue to the International Court of Hague, which by its side recommended the Albanian government to reopen the Greek schools. Found in tough economical position and after none of other Balkan and European countries gave their help, the King Zog was obligated to return to italian "friendship" and together in 1936 signed a series of agreements.
\end{abstract}

In 1931-1936 there have been numerous events that played an important role in Albanian foreign political orientation, which tried to get out of the Italian influence and made lots of efforts to approach with neighboring states and create new policy reports. Because of the change of political course, Italian-Albanian friendly relations until 1931, dilapidated. At this time Tirana government, headed by Ahmet Zogu, took a series of measures, which reaffirmed the independence line and were in opposition to the Italian policy in Albania. A very important action were the measures taken in the field of education to strengthen its national character.

The coming of Hile Mosi on the head of the Albanian education in 1930 and its program regarding the creation of a full and clean national system, escalated the efforts for a national unique and secular school. According to him, the foreigners, especially Italians were using in a bad way their positions as instructors in the Albanian schools, in order to have a political and cultural effect on their students (Duka, 2007).

In August 1932, Hile Mosi in collaboration with Aleksander Xhuvani, as a general secretary of ministry submitted to the king an analytical submission where the key issue was nationalization of education, and among other things was also noted that a great number of Albanian children in the private schools "...Greek, Romanian, Serbian speaking people, Italian people as well as people of different religious communities", were grown up "... with a different culture and feelings from those given to state schools." Therefore was requested that in the new education law be introduced specific provisions so that only the state had the right to open and maintain primary schools (Gogaj, 2004). More specifically, it was requested the change of the fundamental articles of the Albanian state statute that permitted the operation of foreign schools and a number of primary schools in private hands.

This decree-law consisted of three articles that predicted sanctions not only for parents and proctors but also for students themselves. (Puto, 2009). This decree-law did not go for approval in the parliament because of the political conditions and because Hil Mosi died.

After H. Mosi's death, in January 1933, in his place came a specialist and dedicated patriot of the national school, Mirash Ivanaj (Fischer, 1996). He had graduated in the Royal University of Roma, Faculty of Philosophy and Law (Koliqi, 2002).

Thinking about the idea of reforming the Albanian education, Ivanaj started to study the issue, so that he could know better the situation, which was a necessary preliminary need for the reform. After making a report on the state of education in the country, Ivanaj demanded concrete measures. After this summarized presentation of the general state of education, he entered the crucial issue of reform: the one of nationalization and secularization of the education. According to him, it was not possible that in two countries, in two nations, to be implemented one system of schooling and education. Hence, Albania which was holding a special place in Europe as far as it could, needed a special educational 
institution that fit every Albanian thing. According to Ivanaj, this task, could be realized by only one nationwide school, in content and in method (The Albanian history of education and pedagogical thought, 2003).

In these conditions, M. Ivanaj, asked for a change in articles 206 and 207 of the Albanian Statute, which permitted the opening of the foreign schools in Albania. After receiving the approval of the king to the new platform that he introduced, he started to plan what was known in the history as "Ivanaj Reform" (Gogaj, 2004). For this reform, Ivanaj had also the approval of King Zog I, as we mentioned above, he tried to make an independent politics, due to multiple interventions and growing influence of Italy but also as a result of an anti-italian rising tide in country.

In this way, the Albanian Parliament on 1 April 1933, approved a decree-law on the organization of the school system based on articles no. 206 and 207 of the Statute. Under these changes, education and the education of Albanian nationals was compulsory for all and given free by the state, whereas the private schools of all categories were closing. Ministry of Education nationalized all private schools including those where instruction was given only Albanian, to apply wherever a unique national educational program and in minority schools held the teaching of native languages as before (Ushtelenca, 1997). Educational reform had also a series of other amendments that regulated the education system in the country, but our focus will be only on the issue that has to do with the closure of private schools in Albania.

Statute changes accepted by Parliament on April 2, were sanctioned and declared by the king. On April 26 the law was implemented by closing all the private schools in Albania. The new academic year 1933-1934 marked the beginning of the unification of Albanian education, in all categories of schools. Schools that were closed under the educational reform: 21 secular private schools, 14 clerical-Muslim schools, 17 Catholic- clerical schools, 4 Albanian clerical-Orthodox schools, 19 foreign schools for Albanian people, 10 private schools of the Greek minority (The Albanian history of education and pedagogical thought, 2003).

The reform touched the primary professional schools, opened by Italy, especially those catholic in the north, the Greek ones in the south and less the Slavic schools in the area of Shkodra, which passed under the Ministry of Education (Ushtelenca, 1997).

Implementation of the reform hit more private Italian education in Albania, which had four professional schools: in Korca, Gjirokastra, Berat and Shkodra. In the remaining schools was banned the compulsory teaching of Italian, Greek and Serbian. Italians and Greeks were deprived of the right to keep their teachers in these schools. Albanian language became compulsory for all subjects, whereas Italian and Greek were left as foreign languages taught in high schools only. Directorates and teachers were left to Albanians, whereas the educational system and programs would be under the jurisdiction of the Ministry of Education. Even the American Technical School was led by an Albanian director (Ushtelenca, 1997).

Many newspapers and magazines welcomed the M.Ivanaj reform as well as analyzed and evaluated it in some contexts, above all, by considering it as an original, not imported and a not copied Albanian work (The Albanian history of education and pedagogical thought, 2003). "Newspaper of Korca" in on of its articles writes: "The Day of April 25 will remain unforgettable in the history of our reconstruction." By nationalizing the schools, our state resolved permanently, in a heroic way, the issue regarding the growth of the new generation. Almost all the Albanian press organs, inside and outside the country, welcomed the reform as a positive phenomenon on the history of education in Albanian independence period (Gogaj, 2004).

With this measure Parliament and Minister of Education in Albania Ivanaj intended to strengthen the position of school and national culture (History of Albanian People, 2007). Despite the reform aimed at unifying the Albanian education, the reform damaged its infrastructure, because after the closure of the schools, withdrew not only the teaching stuff but also the schools supplies.

All these changes in education law caused dissatisfaction to the government of Rome, to that of Greece as well as the strong anti-government reaction from Catholic clergy.

After the official decision of the Reform, Mussolini authorized the Italian minister in Tirana, Armando Koch, to protest to the King, warning that these measures "which were in contrast with the spirit of the alliance ..., will interfere with the political line of Italy exactly at a time when Albania needed more the Italian support" (Puto, 2009).

Meanwhile, the Albanian Foreign Ministry sent the Italian representatives in Tirana a communication noted that, the need of the Albanian state was that the youth of the country only attended the Albanian schools, because its intention was to instill the love for the motherland and the sense of national unity, which was in conformity with the spirit of cooperation between the Albanian and Italian nations. Later the communication proceeded that, Albania could not allow the uncontrolled activity of the catholic schools, as it will only create the impression that Italy was a patron of the Catholic population, which was contrary to the principles of the Albanian national unity that the nationalization of schools was necessary if we mention the three different religions and that their union could only be reached through schools, which would implemented the directives of the Ministry of Education, and would essentially embodied the idea of national unity. 
"Albania,- continues the communication, - since the beginning, has considered the professional schools as its state institutions, just the technical organization of the schools was trusted to an Italian specialist who was also depended on the Albanian Ministry of Education and that half of their staff were Albanian and got paid by this ministry" (Ushtelenca, 1997).

In the new Italian-Albania tense atmosphere, the biggest debates occurred in the meetings between Mr. Xhafer Vila (Minister of Foreign affairs of Albania) and Armando Koch. The latter complained to Mr.Vila saying that, -"Roma was afflicted by the measures taken in Tirana in the field of education, which had created hostile precedents against Italy and as a minister of Italy in Tirana, he was in a very difficult situation" ( Central State Archive, 1933).

Even as a response to the Education Reform of Albanian government, Mussolini decided the suspension of payment of the loan installments that he gave in 1931. Financial aid was suspended and gradually withdrew all Italian military and civilian personnel. Albanian army supplies with weapons and equipments ceased completely (Fischer, 1996).

The decision for public national school caused also the dissatisfaction of Greek minority. In its area there were 10 private schools, subsidized by the Greek government. Their closure prompted the intervention of Athens government. It accused the Albanian government that had violated the statement that was made in October 1921 before the League of Nations to respect the rights of minorities, it was violated a fundamental right of the minority that of the school in their native language (Puto, 2009). Whereas, the Greek minority itself, addressed with petitions to the king Ahmet Zogu, protesting for this government decision (Lico, 2009).

The issue of private schools became of an international character, because on one hand the Catholic clergy and the Greek government on the other hand, addressed the League of Nations in Geneva.

Greek minority brought the issue to the League of Nations, complaining that Albania Albania had violated the agreement on national minorities, signed by it in 1921. According to the Albanian declaration of 2 October 1921, in the League of Nations, Albanian state guaranteed the national minorities all the rights set out in international norms. So also in the plane of education, Greek minority population, was granted the right to cultivate its language and national culture, through state and private schools. These rights were provided in Albania even to the Serb and Vlach minority (The Albanian history of education and pedagogical thought, 2003).

Meanwhile, numerous protests were made by this minority, while Tirana responded with arrests of key leaders of these Greek movements in the south of the country, which caused riots and damaged Greek-Albanian relations (Fischer, 1996). In support of the minority movement, was also the Greek press, making protests for the so called Greek minority martyrdom in Albania (Gogaj, 2004). Greek newspapers wrote in their articles that Albania was not respecting the minority rights and the functioning of their schools is facing severe obstacles (Greek Press, 1935).

Meanwhile, League Council attributed the review of issue to a committee of experts (British, Mexican, Portuguese). At the beginning of the Committee of the Three in Geneva did not noticed any violation of minority rights by the Albanian government (Gogaj, 2004). However the issue took a legal character and the League Committee on 21 January 1935 led the Greek appeal to the Hague International Court. The court opened in March a process, in front of which both parties presented their views (Puto, 2009).

The defence of the Albanian Party was taken over by the French professor of international law, Gilbert Gidel. He focused on the Greek thesis critic, seeking to burden the Albanian government "an extra task", supplementary, which transcended the minority regime and brought it to the limit of capitulation regime. According to him, the rights of minorities could not be an exclusive right, a privilege in favor of the minority, "The state has the duty and the right to equal treatment of citizens". No country in the world, added Prof-Gidel,- can not give up the care for education. In this case, the Albanian government has taken over all education, has exercised its strict right without harming minority cultural faculties". Whereas in defense of the Greek complaint came out the diplomat N. Politis. He began with a politico-historical submission putting the emphasis as ever on the national conscience "Epirotic" who were described as a privileged, special population, within the Albanian state (Puto, 2009).

Following the Albanian defense Giddel mentioned the fact that in Albania, in proportion to the population, minority had benefited more schools. He stressed that from 72 villages of the Greek minority, 41 of them had fewer than 250 inhabitants and by law, can be excluded from the opening of school; in proportion to the population, Greek speaking people were favored, because if to 1500 Albanian inhabitants belongs one school, 730 Greek inhabitants had one school (Gogaj, 2004).

After the discussion of this issue in Geneva, on 5-18 October 1934, in front of the Albanian Legacy in Athens, vorioepiriot counties organized demonstrations with youth groups, where held speeches even deputies and senators. Whereas the leaders of Greek minority in Albania organized solidarity demonstrations in front of the Greek consulate in Gjirokastra (Gogaj, 2004).

The Albanian delegate in the League of Nations Mr. Lec Kurti, responding to Greek protests, affirmed that 
constitutional amendments of April 1933, education and education of the Albanian citizens became the exclusive prerogative of the state, whereas the private schools of every category was decided to close down, because the state used all of them to apply wherever a nationwide educational program, but the schools of minority villages were left as before, without being touched.

As far as regards the charge that, in the orthodox churches was forbidden the usage of the Greek language, he said that Albanian Autocephalous Church with its legal attributes, since its foundation, had decided to use its national language in the Albanian churches, leaving complete freedom to Greek liturgies in churches of the Greek minority villages. At the end, he declared that, no state has the obligation to give to the national minorities of another state in its territory, more rights than the citizens of the native country and much more, when the international relations were based on the principal of reciprocity, which was not applied on the Albanian population that lived in Greece (Gogaj, 2004).

Head of the Albanian delegation in Geneva, Mehdi Frashri, during a long speech with historical arguments and with his diplomatic delicacy, rejected all the Greek party claims (Gogaj, 2004). Albanian representative declared that the taken measure is justified by the necessary need of the national union (Closure of private schools in Albania in the speech of Mr. Frasheri, in front of the Nations Society, 1935). He mentioned among other things that Albania has always respected and still respects the liabilities toward the League of Nations and that the modifications made in education did not affect at all the minorities. "The Albanian delegate said - Its just the consequence of isolating the secular and religious teaching, that ended up with the closure of the religious schools" (League of Nations Council discussed yesterday the issue of Greek speaking people schools, 1935).

Even the catholic clergy, addressed to the League of Nations, a strong protest concerning the closing of catholic schools by the Albanian government. School issue was one more reason for the exacerbating relations of catholic clergy and Albanian government. It burst into strong criticism in its press against the measures that violated the interests of Albanian catholics (History of Albanian People, 2007).

Through the press, Catholic clergy stand strong in defense of its schools, with historical arguments, in support of the Catholic priests as regards the fields of Albanian education and language. In Shkodra city was created a great tension and turmoil caused by disputes, which were encouraged among students of different religious faiths (History of Albanian Education and Pedagogical Thought, 2003).

In response to the memorandum, Ivanaj came out with the argument that the Reform was not inspired by any grudge against religion but by the desire of the Albanian people to give to the boyhood the same national moral education and an unique academic and cultural learning. What had greater importance, according to Ivanaj, was the fact that, after school nationalization, catholic parents did not make any complain to the government and brought their children to state schools. Later Ivanaj affirmed that catholic people in Albania did not have any limits and they lived with equal rights in all aspects of life (Gogaj, 2004).

Even the local press did not stay indifferent toward this issue. There could be read dozens of articles in support of Albania and the Reform. Besa newspaper under the heading "Albanian minorities before the League of Nations" among other things writes, " with the nationalization reform, Albanian government has only wanted to discipline the education and to control it, aiming the cultural union. This is a right that all the organized states have and can exercise it without any impediment" (Albanian minorities before the League of Nations, 1935).

Finally, in early April 1935, the court took the verdict. With 8 votes pro and 3 against, the court gave the right to the Greek party. Immediately after the court verdict became known in favor of the Greek thesis, Mehdi Frasheri assured the League Council that, Albanian government "will correct what was done wrong... and the Assembly will review the relevant provisions of the Constitution". Schools in the minority areas were reopened in September. Mirash Ivanaj disagreed with the review of reform and resigned from its post as a minister of education (Puto, 2009).

While as regards the conflict with Roma, it will be treated in a bilateral plan, in talks with proposals and counterproposals during the following months, while in July 1934 Albanian government will withdrew in all the relations front with Italy, by accepting to reopen the religious schools and by making the Italian language compulsory in schools of different levels (Puto, 2009). The Italian government did not came out in defense of its schools in Albania, whereas in diplomatic channels there exists lots of documents which show the concern of the Italian state as regards its schools in Albania. Every time in diplomatic channels, Italian government showed no little concern even for the schools of catholic clergy, where the Italian language, literature and culture had an important position in the programs and practices of those schools (History of Albanian Education and Pedagogical Thought, 2003).

Founded in economic difficulties, king Zogu I, was obliged to return to the Italian "friendship". In 1936 were signed a series of agreements with Italy. In this way the signed agreements opened a new page to the history of Italian-Albanian relations. In this agreement was predicted even the opening of private schools where could be allowed the teaching of Italian language. In private schools besides Albanian teaching, as a primary language, could be also taught foreign 
languages, but just in schools approved by the Albanian government. Appointment of foreign teachers would be assigned by Albanian government, but they would not be paid by it. The curriculum in schools of all categories would be based on "national spirit" and every step of it would undergo the state control (Gogaj, 2004).

Educational reform of 1933 was initiated by national interests and its goal was unification and nationalization of education, but it had a negative impact on the Albanian professional education and it led to a crisis in diplomatic relations between Albania and neighboring countries.

\section{References}

Albanian minorities before the League of Nations. (1935, September 28). Besa Newspaper, no. 1266.

Central State Archive of Albania. (1933). Fund 151, File 100.

Central State Archive of Albania. (1934). Fund 151. File. 49

Closure of private schools in Albania in the speech of Mr. Frasheri, in front of the Nations Society. (1935, January 16). Albanian Newspaper, no. 14.

Duka, V. (2007). Albanian History 1912-2000. Tirana: Shblu.

Fischer, B. (1996). King Zog and the effort for stability in Albania. Tirana: Cabej.

Gogaj, I. (2004). Mirash Ivanaj, known personality in the albanian universe. Tirana: Erik.

Greek Press. (1935, December 24). Demokratia Newspaper, no. 486

History of Albanian People. volume III. (2007). Tirana: Toena.

Koliqi, H. (2002). The Albanian History of Education and Pedagogical Thought. Prishtina: Libri Shkollor.

League of Nations Council discussed yesterday the issue of Greek speaking people schools. (1935, January 17). Vatra Newspaper, no. 282

Lico, F. (2009). Problems of Greek-Albanian Relations. Tirana: Neraida.

Puto, A. (2009). The political Albania 1912-1939. Tirana: Toena.

The Albanian History of Education and Pedagogical Thought. volume I. (2003). Tirana: Mother Tereza

Ushtelenca, I. (1997). The Diplomacy of King Zogu I, 1912-1939. Tirana: Ermir. 